\title{
Weed Management in Berseem (Trifolium alexandrium L.): A Review
}

\author{
V.C. Tyagi ${ }^{1 *}$, V.K. Wasnik ${ }^{1}$, M. Choudhary ${ }^{1}$, H.M. Halli ${ }^{1}$ and S. Chander $^{2}$ \\ ${ }^{1}$ ICAR-Indian Grassland and Fodder Research Institute, Jhansi-284003, UP, India \\ ${ }^{2}$ ICAR-Directorate of Weed Research, Jabalpur-482004, MP, India \\ *Corresponding author
}

\begin{abstract}
A B S T R A C T
\section{Keywords}

Berseem, Integrated weed management, Weed

control efficiency,

Herbicides, Cultural

method

Article Info

Accepted:

16 April 2018

Available Online:

10 May 2018

Weeds are the part and partial of crop production since evolution of agriculture. Because of their superiority, efficiently harness favourable microclimate at the cost of crop. They mainly compete for mineral nutrients, soil moisture, space and light interception. In berseem field we can successfully achieve weed control below economic threshold level by adapting both precautionary and curative measures in an integrated manner. In recent days due to labour shortage chemical method of weed control is getting importance but it need to be supplemented with other weed control approaches, which helps in achieving agronomically superior, economically viable and ecologically safe weed control. One year seeding is remains equal to seven year weeding, in this regard integrated weed management is the key for sustainable fodder production in berseem.
\end{abstract}

\section{Introduction}

From the evolution of agriculture, weeds are the part and partial of the crops and causing considerable loss to the crop yield and quality because of their superior characteristics over crops like $\mathrm{C}_{4}$-mechanism, prolific seed production, longer seed viability, dormancy mechanism, competing ability and higher temperature compensation point. They compete with crops for both natural as well as applied resources. Weeds causing annually 45 per cent loss to the Indian agriculture (2000 crores), which is nearly equal to the combined loss due to insects and diseases (Gupta, 2010). Weeds are invading almost all the crops with varied intensity. Fodder crops like berseem also affected by weeds, especially during early growth. Berseem (Trifolium alexandrinum L.) is a one of the most important winter season leguminous fodder crop in India known as king of the fodder crop. After Egypt and Pakistan, India is having the highest area under berseem cultivation (Muhammad et al., 2014). In India, it is grown in approximately 2 million hectares area (Pandey and Roy, 2011). The crop cultivated under irrigated condition provides highly palatable, succulent and nutritious green fodder (800-850 q/ha) in 5-6 cuttings. Berseem fodder has $20 \%$ crude protein, $62 \%$ total digestible nutrients with 
$65 \%$ digestibility. It is well known that feeding of green fodder stimulates and enhances the milk production in dairy animals.

The per unit area productivity of green fodder and seed depends on various agronomical practices i.e. sowing, nutrient, irrigation and cutting management. In spite of this weed has greater impact on fodder and seed production of berseem. Weeds are considered as major biological constraints for limiting the crop productivity. In berseem during early stage of growth period weeds compete with main crops for nutrients, water, light and space thus to achieve the full yield potential of crop the initial 35 to 40 days after sowing crop growth period should be kept weed free (Wasnik et al., 2017).

Due to slow growth of crop weeds adversely affects the crop growth and yield. In berseem, the infestation of weed flora reduces green fodder (23-28\%) and seed (38-44\%) yield fodder (Wasnik et al., 2017). Apart from thisweeds like Cichorium intybus, Rumex dentatus and Sonchus asper pose problems in harvesting of the berseem crop for seed. As, weed management is the major and important part of crop production. The problem of weeds in berseem is very much severe due to lack of appropriate weed control method. Therefore, It is utmost important to control the berseem weeds for enhancement of fodder and seed yield.

\section{Associated weed flora of berseem crop}

The weed flora in berseem field can be grouped into two categories i.e. cropassociated and non-crop associated. In cropassociated weeds Cichorium intybus and Coronopus didymus and in non-crop associated weeds, Anagalis arvensis, Chenopodium album, Ecliptaalba, Medicago denticulata, Melilotus alba, Melilotus indica,
Physalis minima, Rumex dentatus, Sonchus asper, Spergula arvensis,Trifolium resupinatum, Poa annua and Cyperus rotundus are considered to be the most dominating weeds. The berseem field were infested with grassy weeds like Cynodon dactylon, Chloris barbata, Digitaria longiflora, Dactyloctenium aegyptium. Among broad leaved, Amaranthus viridis, Euphorbia geniculata, Celosia argentia, Lantana camara, Trianthema portulacastrum, Commelina benghalensis, Corchorus aestuans, Parthenium hysterophorus, Tridax procumbens, Portulaca oleracea, Cichorium intybus and among sedges, Cyprus rotundus (Pathan and Kamble, 2012). At Uttrakhand, the composition of weed flora observed in the berseem experimental plots were Cichorium intybus, Trianthema portulacastrum, Poa annua, Coronopus didymus and Cyprus rotundus (Joshi and Bhilare, 2006). The prominent weed flora observed on sandy loam soils of Ranchi were Amaranthus viridis, Celosia argentia, Cichorium intybus, Chloris barbata, Commelina benghalensis, Corchorus aestuans, Cynodon dactylon, Cyperus rotundus, Dactyloctenium aegyptium, Digitaria longiflora, Euphorbia geniculata, Parthenium hysterophorus, Portulaca oleracea, Trianthema portulacastrum, Tridax procumbens (Pathan et al., 2013). Prajapati et al., (2015) identified that the major weeds in the berseem field were Polygonum spp, Medicago denticulata, Coronopus didymus, Cyperus rotundus, Cichorium intybus and Vicia spp. under Tarai conditions of Uttarakhand. Gil et al., (1991) reported that, Avena fatua and Thlaspi arvense as the predominant weed flora in berseem.

Singh et al., (2010) noticed Phalaris minor, Avena spp and Poa annua among grasses, Medicago denticulata, Coronopus didymus, Anagallis arvensis, Polygonum plebeium, Melilotus spp. among broad-leaved and Cyperus rotundus, the only sedge as the major 
weed in the berseem field. The major weed flora consisted of berseem were Coronopus didymus, Anagallis arvensis, Melilotus indica, Lathyrus aphaca, Cirsium arvense, Cyperus rotundus, Chenopodium album and Rumex dentatus (Priyanka et al., 2017). Wasnik et al., (2017) observed predominant weed species in berseem in Jhansi condition were Anagalis arvensis, Chenopodium album, Cichorium intybus, Coronopus didymus, Eclipta alba, Medicago denticulata, Melilotus alba, Melilotus indica, Physalis minima, Rumex dentatus, Sonchus asper, Spergula arvensis, Trifolium resupinatum. The dominant weed flora observed in the experimental field of berseem were Cichorium intybus, Cyperus rotundus, Cynodon dactylon, Melilotus indica, Anagalis arvensis, Desmodium tortuosum, Spergula arvensis, Rumex hongifolius, Tridax procumbens and Chenopodium album (Kumar and Dhar, 2008).

\section{Losses caused due to weeds}

However, it has been estimated that the fodder yield loss due to weeds in berseem was nearly 23 to 30 per cent (Joshi and Bhilare, 2006; Alfred, 2012) and seed yield loss was up to $50 \%$ (Jain, 1998) and reported that at earlier stages of growth, berseem faces serious problem with fast growing different weeds. Cichorium intybus found associated with berseem and give more competitional stress by robbing the crop of essential nutrients, light, moisture and space (Thakur et al., 1990). Kewat et al., (2005) observed that among the different weeds, Cichorium intybusis one of the major obnoxious berseem crops associated weed which exert more nutrient and moisture stress.

Weeds in berseem causes substantial reduction (25-30\%) in green fodder production, besides deteriorating the quality of seeds (Tiwana et al., 2002).

\section{Weed control methods}

The weed management is one of the vital components of berseem cultivation particularly for seed production. They compete with crops for natural and applied resources besides being responsible for reducing quantity and quality of agricultural productivity (Rao and Nagamani 2010, 2013; Rao et al., 2015). In order to reduce weed growth, many "weed control" strategies have been developed in order to control the growth and spreads of weeds.

Traditionally, weed control in India has been largely dependent on manual weeding. However, increased labour scarcity and costs are encouraging farmers to adopt labour and cost saving options. A much wider range and intensity of weeds occur in berseem. Weeds vary in their growth habit and life cycle. Therefore, no single weed control method may provide effective control of weed. Various weed management practices are in vogue and each has its own pros and cons. The choice of any weed control method depends on its effectiveness and economics. The various weed management practices can be grouped into three broad categories namely cultural and preventive; physical or mechanical and chemical weed control. These practices are discussed as under,

\section{Preventive and cultural methods}

Menace of weeds in berseem can be curbed effectively with the adoption of preventive methods. Deep summer ploughing with soil inversion plough after harvest of the crop is very effective way to reduce the weed count. Use of clean seeds and cultural practices such as time and method of sowing, crop rotation, dose, method and time of fertilizer application, time and method of irrigation have pronounced effect on weed crop interference. 


\section{Use clean seeds}

In berseem, seeds contaminated with weed seeds is a major factor responsible for the spreading of weeds particularly chicory (Chicorium intybus). The intensity of this weed could be reduced by the use of weed free berseem seeds for sowing or making the berseem seed weed free by pre sowing treatment of berseem seeds with $10 \%$ salt solution is most commonly used for eliminating the problem of Chicory including the other weed seeds in berseem crop (Joshi and Bhilare, 2006; Kumar and Dhar, 2008). The chicory seeds being lighter in weight then berseem seed float on the surface while berseem seeds settle down at the bottom of container. In this way chicory seeds may be drained off and berseem seed collected. ICAR-IGFRI, Jhansi in collaboration with ICAR-CIPHET, Ludhiana developed berseem-chicory seed separator for separating chicory seeds from berseem seeds. Slight differences in shape of seeds (the round shape and smooth texture of berseem and triangular shape and rough texture of chicory seeds), physical properties related to surface property and aero dynamics behaviour of both the seeds were used for separating chicory and berseem seeds (ICAR-IGFRI, 2011).

\section{Crop rotation}

Crop rotation is an important component of integrated weed management. Weeds with the same life cycle as the crop tend to increase under monoculture. Adopting proper crop rotation practices will help in overcoming the domination of certain weeds and reducing the weed competition in berseem based cropping systems. Inserting crop having different seeding and maturity time can break the life cycle of some economically important annual weeds. An important reason for rotating crops is to deplete the soil weed seed bank. Growing alternate crops in place of berseem for two or more years, soil weed seed banks decline to low levels where they can be more easily managed. Crop rotation has been found a very effective cultural practice in breaking the association of problematic weeds like chicory in berseem. Rotation of berseem fields with other crops like wheat, chickpea and mustard helps in reducing the population of chicory.

\section{Sowing methods}

Generally, berseem seeds are sown by broadcasting in 5-6 cm standing water. This helps in rapid germination and easy establishment of young seedlings. The use of seed drill is advantageous as line sowing helps in optimum seed placement resulting in uniform plant population. It also helps in easy inter-cultivation and recommended for seed production per se. Berseem seed drill was developed by IGFRI, Jhansi for line sowing of berseem in proper depth.

\section{Physical and mechanical methods}

Hand weeding in crops is as old as agriculture itself. It involves the removal of weeds by various tools and implements including hand weeding and uprooting. Manual weeding though effective but involves considerable amount of man-power and time. Due to costly and scarce labour, its feasibility is very less. Mechanical weeding is also difficult in broadcast sown wheat. However, mechanical control can be practiced effectively in line sowing seed crop of berseem. In a field trial on sandy clay loam soil of Jabalpur, Jha et al., (2014) found that, Cichorium intybus, Medicago denticulata and Cornopus didymus as the dominant weeds. Hand-hoe was the most effective in controlling weeds which produced higher green fodder (612 q/ha) and seed yield (3.74 q/ha) compared to 266 and $1.57 \mathrm{q} / \mathrm{ha}$ in unweeded plots, respectively. Since the initial slow growth stage, two hands 
weeding (3 and 5 weeks after sowing) should be done. At Pantnagar, Prajapati et al., (2015) observed that manual weeding twice 3 and 5 weeks after sowing reduced weed dry weight from 85.8 to $45.9 \mathrm{~g} / 0.25 \mathrm{~m}^{2}$ and increased the berseem seed yield from 3.50 to $4.10 \mathrm{q} / \mathrm{ha}$ as compared to unweeded control. Similarly, Pathan et al., (2013) also found lower weed density with hand weeding at 3 and 5 week after sowing. The weed control efficiency was also higher under manual weeding than herbicide Pendimethalin/oxyflourfen at 0.1 $\mathrm{kg} / \mathrm{ha}$ as pre emergence and imazethapyr at $0.1 \mathrm{~kg}$ ai $/$ ha as post emergence.

\section{Chemical method}

Herbicides are effective tools in man's eternal struggle with weeds. When properly used, herbicides can safely and effectively accomplish their objective. Chemical weed control is preferred because of its better efficiency along with less cost and time involvement. Also, it causes no mechanical damage to the crop that happens during manual weeding. Moreover, the control is more effective as the weeds even within the rows are killed, which invariably escape, because of morphological similarity to crop, during mechanical control. Effective weed control depends on the proper selection of herbicides depending on the type of weed flora infesting the crop and further herbicide should be applied at optimum dose and time using proper application technology.

Traditionally, weed control in India has been largely dependent on manual weeding. However, increased labour scarcity and costs are encouraging farmers to adopt labour and cost saving options. In recent decades the predominant weed control method in many parts of the world is the use of effective and reliable chemical herbicides. Among the pesticides sold, herbicides occupy $16 \%$ share in India (Choudhury et al., 2016).
Jha et al., (2014) observed that menace of broad leaved weeds in berseem could be curbed selectively and economically with pre emergence application of oxyfluorfen @ $0.100 \mathrm{~kg}$ a.i./ha + imazethapyr @ $0.15 \mathrm{~kg}$ a.i./ha (immediate after harvest of $1^{\text {st }}$ cut). Similarly, post emergence (3 WAS) application of imazethapyr at $0.10 \mathrm{~kg}$ a.i./ha and butachclor at $1.5 \mathrm{~kg} / \mathrm{ha}$ as pre-emergence were effective in controlling weeds at Hisar (Priyanka et al., 2017). In the clay soil of Rahuri, pre-emergence application of oxyflourfen at $0.1 \mathrm{~kg} / \mathrm{ha}$ followed by imazethapyr as post-emergence at $0.10 \mathrm{~kg} / \mathrm{ha}$ effectively controlled weeds and it was found at par with one hoeing at 3 week after sowing and one hand weeding at 5 week after sowing and imazethapyr as post-emergence at 0.10 $\mathrm{kg} / \mathrm{ha}$ (Pathan et al., 2013). In sandy loam soils of Jharkhand where water is limiting factor pre-emergence application of pendimethalin at $0.3 \mathrm{~kg}$ a.i/ ha + imazethapyr at $0.1 \mathrm{~kg} \mathrm{a.i} /$ ha (after the first and second cut) was found effective to control weeds in berseem. Higher dose of pendimethalin at 0.5 $\mathrm{kg}$ a.i/ ha along with Imazethapyr at $0.1 \mathrm{~kg}$ a.i/ ha after first cutting reduces the growth of berseem (Kumar et al., 2018). Fifty per cent reduction in berseem population was also observed due to phytotoxic effect of pendimethalin when applied as preemergence or at 7 days after sowing. However, post emergence application at 14 days after sowing was safe and produced the maximum green fodder yields (Mishra, 2012). Pre-emergence application of oxyflourfen at $0.1 \mathrm{~kg} / \mathrm{ha}+$ imazethapyr at $0.10 \mathrm{~kg} / \mathrm{ha}$ after first cut of berseem found most productive and remunerative in Pune region of Maharashtra (Kauthale et al., 2016). Preemergence application of imazethapyr at 0.1 $\mathrm{kg}$ a.i./ha reduced the population of weeds including Cichorium intybus in Jhansi (Kumar and Dhar, 2008). However, post emergence application of imazethapyr after first and second cut was found effective for control of 
weeds and obtaining higher yield and remunerations at Rahuri (Sinare et al., 2017). However, in clay loam soils of Gurdaspur Punjab, application of fluchloralin at 0.45 $\mathrm{kg} / \mathrm{ha}$ or oxyfluorfen at $0.1 \mathrm{~kg} / \mathrm{ha}$ followed by imazethapyr at $0.075 \mathrm{~kg} / \mathrm{ha}$ appeared more useful for effective weed control in berseem which resulted in maximum green fodder and seed yield (Chopra and Saini, 2017).

\section{Integrated weed management}

Integrated weed management (IWM) is an approach which involves the utilization of all weed control techniques (cultural, physical, biological and chemical) in a series to keep the weed population below the level of economic injury to crop. Kantwa et al., (2017) recorded the lowest weed dry weight at first $\left(29.81 \mathrm{~g} / \mathrm{m}^{2}\right)$ and second cut $(66.30$ $\mathrm{g} / \mathrm{m}^{2}$ ) and highest total green fodder yield (3.61 t/ha) from stale seed bed (10 days before sowing) + propaquizafop at $0.1 \mathrm{~kg}$ a.i./ha as post emergence.

\section{Effect of weed control measures on}

\section{Weed density}

Berseem is severely infested with weeds, many workers reported more than 100 weeds in one $\mathrm{m}^{2}$ area (Pathan et al., 2012; Jha et al., 2014; Kumar and Dhar, 2008). Pathan et al., (2012) found 114 weeds $/ \mathrm{m}^{2}$ in weedy check plot, out of this 76 were monocot and 38 were dicot. Application of Oxyflourfen at $0.100 \mathrm{~kg}$ a.i.ha ${ }^{-1}$ reduced monocot, dicot and total weed count to $21.7,8.3$ and $30.3 \mathrm{~m}-2$, respectively. Imazethapyr at $0.1 \mathrm{~kg}$ a.i. $\mathrm{ha}^{-1}$ immediate after harvest of $\mathrm{I}^{\text {st }}$ cut was found at par. However, application of imazethapyr at $0.1 \mathrm{~kg} / \mathrm{ha}$ after first and second cut reduced the weed density from 101 to 33 at Rahuri (Sinare et al., 2017). In sandy loam soil of Hisar, Priyanka et al., (2018) observed the highest population of Coronopus didymus 8, 12.8 and 14.7 plants $/ \mathrm{m}^{2}$, at 30, 60 and 120 days after sowing in weedy check plot, respectively. Application of Imazethapyr at $0.1 \mathrm{~kg} / \mathrm{ha}$ as pre emergence completely controlled the population of swine cress (Jha et al., 2014). At Jhansi, Kumar and Dhar (2008) observed that out of 127 of total weeds $/ \mathrm{m}^{2} 48$ plants were chicory in weedy check plot. Imazethapyr at $0.1 \mathrm{~kg} / \mathrm{ha}$ was found better to control chicory population followed by common salt treatment. However, tank mix of oxyflourfen at 0.10 $\mathrm{kg} / \mathrm{ha}+$ imazethapyr at $0.10 \mathrm{~kg} / \mathrm{ha}$ (immediate after harvest of $\mathrm{I}^{\text {st }}$ cut) reduced weed density than sole application of either (Kauthale et al., 2016).

\section{Weed dry weight}

Highest weed dry weight $\left(40.22 \mathrm{~g} / \mathrm{m}^{2}\right)$ of weeds were recorded in weedy check plot at Ranchi. It was significantly reduced due to application of pendimethalin at $1.0 \mathrm{~kg} / \mathrm{ha}+$ imazethapyr at $0.15 \mathrm{~kg} / \mathrm{ha}$ immediate after $1^{\text {st }}$ cut (Kumar et al., 2017). However, oxyflourfen at $0.10 \mathrm{~kg} / \mathrm{ha}$ or imazethapyr at $0.10 \mathrm{~kg} / \mathrm{ha}$ immediate after harvest of $\mathrm{I}^{\text {st }}$ cut registered the lowest $(0.05 \mathrm{t} / \mathrm{ha})$ dry weight of weed at harvest in Pune (Kauthale et al., 2016; Sinare et al., 2017). In silty clay loam Pantnagar Physical method like one hoeing at 3 weeks + one hand weeding 5 weeks after sowing was reduced weed dry matter at par with pendimethalin at $1.0 \mathrm{~kg}$ a.i./ha + imazethapyr at $0.15 \mathrm{~kg}$ a.i./ha (Prajapati et al., 2015).

Brajkishor et al., (2015) found that, significantly less weed dry weight in case of Pendimethalin at $1.0 \mathrm{~kg}$ a.i./ha + Imazethapyr at $0.15 \mathrm{~kg}$ a.i./ha applied immediately after $1^{\text {st }}$ cut. Total weed dry matter in weedy check plot was $560 \mathrm{~kg} / \mathrm{ha}$ out of which $190 \mathrm{~kg}$ was chicory. Application of imazethapyr reduced to $100 \mathrm{~kg} / \mathrm{ha}$ at Jhansi (Kumar and Dhar, 2008). However, at Pantnagar total weed dry matter was $215 \mathrm{~g} / \mathrm{m}^{2}$ in weedy plot and 
butachlor at $0.1 \mathrm{~kg} / \mathrm{ha}$ as pre emergence reduced it to $149 \mathrm{~g} / \mathrm{m}^{2}$ (Joshi and Bhilare, 2006).

\section{Weed control efficiency}

It indicates the efficiency of the applied herbicide or other practices to control weeds. It is the percentage reduction in weed dry matter by any weed control treatment in comparison to weedy check plot. This index is used to compare the different weed control treatments. Higher the WCE of any treatment, better is the treatment, and vice versa. Jha et al., (2014) stated that WCE of oxyfluorfen at $0.100 \mathrm{~kg}$ a.i./ha $\mathrm{PE}+$ imazethapyr at $0.150 \mathrm{~kg}$ a.i./ha (72.3\%) was almost similar to oxyfluorfen at $0.10 \mathrm{~kg}$ a.i./ha + one hand weeding at 5 weeks after sowing (69.29\%). May workers also reported similar results (Pathan et al., 2013; Sinare et al., 2017; Kauthale et al., 2016 and Prajapati et al., 2015) used pendimethlin at $1.0 \mathrm{~kg} / \mathrm{ha}$ instead of oxyfluorfen to control weeds and got higher WCE. Higher weed control efficiency with 2 hand weeding has been reported earlier (Aggarwal et al., 2014). Application of imazethapyr at $0.1 \mathrm{~kg} / \mathrm{ha}$ at 3 weeks after sowing (WAS) is able to control weeds to considerable extent (65-75\%) (Priyanka et al., 2018). However, Kumar et al., (2017) managed more than $80 \%$ weeds through application of pendimethalin at $0.3 \mathrm{~kg}$ a.i./ ha. Singh et al., (2010) tested alachlor $2.0 \mathrm{~kg} / \mathrm{ha}$ and Joshi and Bhilare, (2006) tested Butachlor at $1.0 \mathrm{~kg}$ ai $/ \mathrm{ha}$ as $\mathrm{PE}$ and found higher weed control efficiency (70-83\%).

\section{Growth and yield components}

It is well known fact that weeds adversely affects yield and quality of fodder. Application of herbicides not only improves fodder yield but also quality. Kumar et al., (2017) recorded 479 q/ha green fodder yield with pendimethalin at $1.4 \mathrm{~kg}$ ai/ha as against
$310 \mathrm{q} / \mathrm{ha}$ in weedy plot. However, Samunder (2012) reported highest green fodder yield with the application of trifluralin at $0.75 \mathrm{~kg} / \mathrm{ha}$ which was statistically similar to weed free plot. Pre-emergence application of oxyflourfen at $0.10 \mathrm{~kg} / \mathrm{ha}$ followed by postemergence application of imazethapyr at 0.10 $\mathrm{kg} / \mathrm{ha}$ immediate after harvest of $\mathrm{I}^{\text {st }}$ cut recorded significantly higher yield values of green fodder (Kauthale et al., 2016). Agrawal et al., (2001) also registered the highest green fodder yield with pre-emergence application of butachlor at $1.5 \mathrm{~kg} \mathrm{ha}^{-1}$ and it was comparable to hand weeding twice. Similarly, Tiwana et al., (1985) obtained 29 and 31\% higher green and dry matter yields of berseem with fluchloralin at $0.6 \mathrm{~kg} \mathrm{ha}^{-1}$ over the weedy plot, respectively. Application of imazethapyr at $0.1 \mathrm{~kg} / \mathrm{ha}$ improved green fodder yield by about $76 \%$ over weedy check at Jhansi (Kumar and Dhar, 2008). Pathan and Kamble (2012) observed that berseem plants in weedy plots were taller than herbicide treated. Higher weed density created more completion for the sunlight with the berseem crop resulted in more plant height in weedy check.

\section{Economics}

The application of imazethapyr at $0.1 \mathrm{~kg}$ a.i./ha found to be the most remunerative and effective herbicide for controlling the complex weed flora in berseem at Jhansi (Wasnik et al., 2017; Kumar and Dhar, 2008; Priyanka at el, 2017). Similarly, Sinare et al., (2017) also recorded maximum mean gross returns ( $\square$ 96,520/ha), net returns of ( $\square$ 48,970/ha) and B-C ratio (2.09) were recorded due to application of imazethapyr at $0.1 \mathrm{~kg} / \mathrm{ha}$ after $1^{\text {st }}$ and $2^{\text {nd }}$ cut. However, Kauthale et al., (2016) tried combination of two herbicides at Pune, pre-emergence application of oxyflourfen at $0.10 \mathrm{~kg} / \mathrm{ha}$ and post-emergence application of imazethapyr at $0.10 \mathrm{~kg} / \mathrm{ha}$ immediately after $\mathrm{I}^{\mathrm{st}}$ cut recorded maximum net monetary returns $(\square$ 
1,34,048/ha) and B:C ratio (3.43). Pathan et al., (2012) also obtained similar results in Rahuri, while, Kewat et al., (2005) realised higher monetary returns with butachlor at 2 $\mathrm{kg}$ ai/ha as pre-emergence application.

Weeds deplete a large quantity of mineral nutrients, moisture, shade the crop (light interception) and occupy the space. Berseem field is most predominantly affected by Dicotyledonous weeds. The above stated review results reveals that, weeds should be controlled for successful crop production. The suitable weed control strategies like cultural control, mechanical methods, herbicide adoption and integrated approaches or individual will significantly decrease the weeds, which will lead to even greater yields. Chemical weed control is getting importance in areas, where labour is scarce and costly. Some of the herbicides either alone or their combinations at lower dose have been proved economically viable alternative to hand weeding in management of weeds in berseem field. However, integrated weedmanagement is the key to sustainable crop production throughout the world and will remain the mainstay for weed control for the foreseeable future.

\section{References}

Aggarwal, N., G. Singh, H. Ram and Khanna, V. 2014. Effect of post-emergence application of imazethapyr on symbiotic activities, growth and yield of blackgram (Vigna mungo) cultivars and its efficacy against weeds. Indian $\mathrm{J}$. Agronomy. 59(3): 421-426.

Agrawal, S. B., K. M. Dubey and Thakur, G. S. 2001. Chemical weed control in berseem with special reference to Cichorium intybus. First Biennial Conference in New Millennium on "Eco-friendly Weed ManagementOptions for Sustainable Agriculture, held during May 23-24, 2001, at University of Agril. Sciences, Bangalore pp. 104.

Alfred, S. 2012. Evaluation of herbicides for weed management in berseem (Trifolium alexandrinum L.). M.Sc. Thesis. G.B. Pant Uni. of Agric. And Tech., Pantnagar.

Birendra, K., J. K. Kerketta and Singh, U. K. 2017. Efficacy of different herbicide in berseem (Trifolium alexandrinum L.) under medium land condition of Jharkhand. Chemical Science Review and Letters. 6(24): 2442-2447.

Chopra, S. and Saini, M. K. 2017. Assessment of various herbicides in berseem under sub-mountainous conditions of Punjab. In: Biennial Conference of the Indian Society of Weed Science on Doubling Farmers Income by 2022: The Role of Weed Science, MPUAT, Udaipur, India during 1-3 March, 2017. Pp. 98.

Choudhury, P. P., R. Singh, D. Ghosh and Sharma, A. R. 2016. Herbicide use in Indian agriculture. ICAR - Directorate of Weed Research, Jabalpur, Madhya Pradesh, pp 110.

Dheer S, Y. P. Joshi S. Virpal and Sachan H. K. 2010. Chemical weed management in Berseem (Trifolium alexandrium L.). Pantnagar Journal of Research. 8(1): 57.

Gupta, O. P. 2010. Weed Management Principles and Practices. Agrobios publications, Pp: 80-85.

IGFRI. 2011. Annual Report 2010-11. ICARIndian Grassland and Fodder Research Institute, Jhansi, Pp 48-49.

Jain, K. K. 1998. Floristic composition of berseem-weed ecosystem on weed dynamics. World Weeds. 5: 37-39.

Jha, A. K., A. Shrivastva, N. S. Raghuvansi and Kantwa, S. R. 2014. Effect of weed control practices on fodder and seed productivity of Berseem in Kymore plateau and Satpura hill zone of Madhya 
Pradesh. Range Management and Agroforestry. 35(1): 61-65.

Joshi, Y. P. and Bhilare, R. L. 2006. Weed management in berseem (Trifolium alexandrinum L.). Pantnagar Journal of Research. 4(1): 15-17.

Kantwa, S. R., D. R. Palsaniya and Prabhu, G. 2017. Effect of weed management practices on fodder yield and weed biomass in berseem (Trifolium alexandrinum L). In: National Symposium on "New Directions in Managing Forage Resources and Livestock Productivity in 21st Century: Challenges and Opportunities" during March 3-4, 2017, RVSKVV, Gwalior, India. pp 165.

Kauthale, V. K., P. S. Takawale. and Patil, S. D. 2016. Weed management in berseem. Indian Journal of Weed Science 48: 300-303.

Kewat, M. L., S. B. Agrawal and Shukla, V. K. 2005. Effect of weed control on seed yield of Berseem (Trifolium alexandrinum L). Forage Research. 31: 78-80.

Kumar, B., S. Kumar and Singh U. K. 2018. Yield and economics of berseem (Trifolium alexandrinum L) influenced by herbicide under slight acidic alfisol soil of Jharkhand. International Journal of Chemical Studies. 6(1): 83-86.

Kumar, S. and Shivadhar. 2008. Influence of different herbicides on weed suppression, forage yield and economics of berseem (Trifolium alexandrinum L). Indian Journal of Agricultural Sciences. 78: 954-956.

Mishra, J. S. 2012. Management of dodder in Lucerne and Egyptian clover. Indian Journal of Weed Science. 44(1): 6-10.

Muhammad, D., B. Misri, E. L. Nahrawy, M. S. Khan and Serkan, A. 2014. Egyptian clover (Trifolium alexandrinum L.): King of forage crops. FAO Regional, Cairo.
Pandey, K. C. and Roy, A. K. 2011. Forage crops varieties. ICAR-Indian Grassland and Fodder Research Institute, Jhansi, India. pp 93.

Pathan, S. H. and Kamble, A. B. 2012. Chemical weed management in berseem (Trifolium alexandrium L.). Forage Research. 38 (3): 138-143.

Pathan, S. H., A. B. Kamble and Gavit, M. G. 2013. Integrated weed management in Berseem. Indian Journal of Weed Science. 45(2):148-150.

Prajapati, B., T. C. Singh, P. Giri and Kewalanand. 2015. Efficacy of herbicides for weed management in berseem. The Bioscan, an International Quarterly Journal of Life Sciences. 10(1):347-350.

Priyanka, R. S. Sheoran, S. S. Punia and Singh, S. 2018. Studies on chemical weed control in berseem (Trifolium alexandrinum L.) International Journal of Current Microbiology and Applied Sciences. 7(1): 2669-2673.

Priyanka, R. S. Sheoran, S. Singh and Punia, S. S. 2017. Effect of butachlor, pendimethalin, imazethapyr and oxadiargyl on yield, quality and economics of berseem fodder (Trifolium alexandrinum L.). Forage Research 43 (3): 219-222.

Rao, A. N. and Nagamani, A. 2010. Integrated weed management in IndiaRevisited. Indian Journal of Weed Science. 42: 1-10.

Rao, A. N. And Nagamani, A. 2013. Ecoefficient weed management approaches for rice in tropical Asia. Proc. 4th Tropical Weed Science Conf. Weed Management and Utilization in the Tropics held during January 23-25, 2013, The Empress Hotel, Chiang Mai, Thailand, p. 78-87.

Rao, A. N., S. P. Wani, M. Ramesha and Ladha, J. K. 2015. Weeds and weed 
management of rice in Karnataka state, India. Weed Technol. 29(1): 1-17.

Sinare, B. T., H. P. Pardeshi and Gavit, M. G. 2017. Sequential use of herbicides for weed control in Egyptian clover. Indian Journal of Weed Science. 49(3): 269271.

Singh, S. 2012. Studies on weed management in berseem (Trifolium alexandrinum L.). Haryana Journal of Agronomy 28(1\&2): 77-80.

Stallknecht, G. F., D. M. Wichnan, L. Thormpson and Keener, T. 1991. Effect of herbicides on yield, plant vigor and weed control in berseem clover. Montana-Ag. Research. 8 (1): 26-29.

Thakur, G. S., R. K. Dubey and Tripathi, A. K. 1990. Evaluation of herbicides for weed management in berseem, pp. 55.
In: Biennial Conference of ISWS, held during March 4-5, 1990 at JNKVV, Jabalpur.

Tiwana, M S., T. Singh, L. S. Brar and Singh, T. 1985. Cooperative bio-efficacy of different herbicides against Poa апnиa in berseern. Pesticides. 19 (6): 52- 54.

Tiwana, U. S., K. P. Puri, M. S. Tiwana and Walia, U. S. 2002. Effect of butachlor, trifluralin and fluchloralin on chicory (Cichorium intybus) and berseem fodder. Indian Journal of Weed Science. 34 (3\&4): 251-253.

Wasnik, V. K., A. Maity, D. Vijay, S. R. Kantwa, C. K. Gupta and Kumar, V. 2017. Efficacy of different herbicides on weed flora of berseem (Trifolium alexandrium L.). Range Mgmt. \& Agroforestry. 38 (2): 221-226.

\section{How to cite this article:}

Tyagi, V.C., V.K. Wasnik, M. Choudhary, H.M. Halli and Chander, S. 2018. Weed Management in Berseem (Trifolium alexandrium L.): A Review. Int.J.Curr.Microbiol.App.Sci. 7(05): 1929-1938. doi: https://doi.org/10.20546/ijcmas.2018.705.226 